DOI https://doi.org/10.32782/2305-9389/2020.22.17

УДК 614.2

Криничко Лілія,

кандидат медичних наук, здобувач кафедри економічної безпеки, публічного управління та адміністрування Державного університету "Житомирська політехніка»

\title{
ЕТАПИ РЕФОРМУВАННЯ СИСТЕМИ ОХОРОНИ ЗДОРОВ'Я В НЕЗАЛЕЖНІЙ УКРАЇНІ
}

\begin{abstract}
У статті визначено етапи реформування системи охорони здоров'я в Україні, які виділяють вітчизняні вчені, а також з'ясовано напрями, які ними пропонуються для вдосконалення. Загалом вважаємо, щүо для реалізаціі ефективних методів удосконалення системи охорони здоров'я потрібно на державному рівні визначити стратегічні напрями розвитку досліджуваної галузі з обмеженням впливу політичних змін. Це дозволить забезпечити в повній мірі реалізацію стратегї та уникнути фрагментарних реформ. У статті досліджено сутність та значення державного регулювання ринку приватної медицини, а також висвітлено особливості системи охорони здоров'я як вкрай важливого сектора сочіально-економічного життя з точки зору забезпечення сочіальноекономічної та політичної стабільності держави. Проаналізовано ключові засади отримання позитивних результатів у політиці державного управління медичними закладами. Окреслено, щзо за державної підтримки розвитку ринку медицини та мінімізації перешкод розвитку галузі створення сприятливих умов для фінансування системи охорони здоров'я в иілому є досить імовірним. Проведено огляд основних иілей державного регулювання ринку медицини України. Доведено, щзо реалізація права людини на якісні медичні послуги зумовлює спрямування політики держави в Україні на реформування чинної системи охорони здоров'я та створення ефективної національної моделі. Охарактеризовано завдання, які стоять перед державним управлінням шчодо реформування системи охорони здоров'я, у свою чергу зазначені завдання визначають зміст та форму реалізації тієї чи іншої реформи у сфері охорони здоров'я як ключового складника соціальної політики держави. Виявлено, щчо зміни в стратегії державного управління приватними медичними закладами є необхідною передумовою розвитку кардинально нового, потенційно здорового суспільства. Здійснено періодизацію прочесів реформування системи охорони здоров'я України.
\end{abstract}

Ключові слова: система охорони здоров'я, медицина, медичні заклади, медичні послуги, державне регулювання медичними закладами.

\section{Krynychko Lilia. Stages of reforming the healthcare system in independent Ukraine}

The article identifies the stages of reforming the health care system in Ukraine, which are identified by domestic scientists, as well as clarifies the areas they propose for improvement. In general, we believe that in order to implement effective methods of improving the health care system, it is necessary to determine at the state level the strategic directions of development of the research area with limiting the impact of political change. This will ensure full implementation of the strategy and avoid fragmentary reforms. The article examines the essence and importance of state regulation of the market of private medicine, as well as highlights the features of the health care system as an extremely important sector of socio-economic life in terms of socio-economic and political stability of the state. The key principles of obtaining positive results in the policy of public administration of medical institutions are analyzed. It is emphasized that with the state support of the development of the medical market and minimization of obstacles to the development of the industry, the creation of favorable conditions for financing the health care system as a whole is highly probable. A review of the main objectives of the Ukrainian state regulation medical market is described. It is proved that the realization of the human right to quality medical services determines the direction of the state policy in Ukraine on reforming the current health care system and creating an effective national model. The tasks facing the public administration in reforming the health care system are described, in turn; these tasks determine the content and form of implementation of a reform in the field of health care as a key component of social policy. It was found that changes in the strategy of public administration of private medical institutions are a necessary prerequisite for the development of a radically new potentially healthy society. Periodization of the processes of reforming the health care system of Ukraine has been carried out.

Key words: health care system, medicine, medical institutions, medical services, state regulation by medical institutions.

Актуальність теми. Система охорони здоров’я України є досить мінливою до реформ у галузі державного управління. Це зумовлено тим, що охорона здоров'я є складовою частиною соціальної політики держави та завжди знаходиться на перетині соціальних інтересів більшості членів суспільства. «Охорона здоров'я є найважливішою сферою діяльності для благополучного й успішного розвитку будь-якої країни і територіального утворення. Від організаційної, фінансово-економічної, кадрової готовності надавати якісну і доступну медичну допомогу населенню залежать стійкість економічного 
розвитку країни і соціальна стабільність у суспільстві» [1, с. 31]. Відповідно, політичні еліти з метою збереження свого авторитету та місця на політичній арені приділяють даному питанню значну увагу. Зазвичай під час зміни політичної влади в країні розроблялися нові підходи до реформування системи охорони здоров'я. 3 метою розроблення науково обгрунтованих напрямів розвитку системи охорони здоров'я необхідним є оцінка існуючих програм, стратегій та концепцій розвитку охорони здоров'я, які були розроблені міжнародними, громадськими, аналітичними організаціями та органами центральної виконавчої влади чи органами місцевого самоврядування. Це дозволить оцінити наслідки реформ і визначити напрями розвитку науки державного управління та сформувати інноваційні підходи до реформування системи охорони здоров'я України.

Аналіз останніх досліджень. Питання оцінки напрямів розвитку системи охорони здоров'я піднімалися в наукових працях вітчизняних учених, зокрема таких, як: В.М. Лехан, Л.В. Крячкова, М.І. Заярський, Г.О. Слабкий, М.В. Шевченко, А.Д. Барзилович, В.М. Пашков, С.В. Петрова, О. Фірсова, О. Заглада, Н. Кризина та інші.

Виклад основного матеріалу. Питання реформування системи охорони здоров'я для України є не новим та завжди актуалізується в умовах зміни політичних еліт. Значна увага до нього пов'язана з незадоволеністю системою охорони здоров'я більшості членів суспільства. «Для успішної реалізації трансформацій системи медичного обслуговування в Україні нагально необхідними є: формування політики, яка базується на цілісній, виваженій, прийнятій консенсусом стратегії реформи охорони здоров'я; розробка адекватного нормативно-правового забезпечення, збалансованого з конституційними нормами; застосування сучасних управлінських підходів: управління змінами та проектного підходу; постійний моніторинг та оцінка для швидкого реагування на виклики і ризики, які виникають в процесі реформування, а також ретельна підготовка керівників та працівників фінансово-економічних підрозділів органів та закладів охорони здоров'я щодо роботи в нових фінансово-економічних умовах» [8, с. 8].

Вітчизняний вчений В.С. Костюк з даного приводу вказує: «нині в Україні станом охорони здоров’я незадоволені всі: і громадяни, і медичні працівники, і уряд, і Верховна Рада. Українська система охорони здоров'я не здатна повною мірою задовольнити потреби населення в медичній допомозі, забезпечити іiі доступність і належну якість, необхідний рівень профілактики захворюваності, зниження смертності, збільшення тривалості життя населення. Медична реформа не лише назріла, а й певним чином перезріла. Реалізація права людини на якісні медичні послуги зумовлює спрямування політики держави в Україні на реформування чинної системи охорони здоров'я та створення ефективної національної моделі. Виконанню цього завдання сприятиме аналіз досвіду організації медичної сфери в країнах, системи охорони здоров'я яких визнано успішними. Руйнація системи охорони здоров'я Семашка (бюджетне утримання медичної інфраструктури) в Україні дає нашій державі унікальний шанс створити нову модель, яка буде побудована на сучасних досягненнях, і враховувати позитивний досвід організації охорони здоров'я світового співтовариства» [8, с. 9].

Досить цікавою є позиція Л.З. Буранбаєвої щодо причин повільності реформування системи охорони здоров’я в кранах світу, особливо країнах пострадянського простору: «Реформа в охороні здоров’я здійснюється вкрай повільно. $Є$ значні труднощі в реструктуризації цієї сфери. Низькі темпи структурних перетворень у системі охорони здоров'я зумовлюються значною мірою недосконалістю системи управління - передусім iï фрагментацією, ослабленням функцій стратегічного і поточного планування, недостатнім розвитком механізмів координації різних суб'єктів управління. Муніципалізація охорони здоров'я помітно знизила можливості побудови раціональної системи охорони здоров'я. Кожне муніципальне утворення будує свою замкнену систему охорони здоров'я. Місцеві органи з політичних міркувань схильні містити надмірну кількість медичних установ і підприємств, ніж іти на кооперацію з іншими муніципальними утвореннями. Жорстка прив'язка фінансування до конкретних муніципальних підприємств і установ, неможливість перерозподілу фінансових ресурсів призводять до нераціонального їх використання як в окремому муніципальному окрузі, так і в суб'єкті Федерації загалом. Часто приймаються рішення, які суперечать регіональній стратегії розвитку охорони здоров'я (наприклад, щодо перерозподілу частини обсягів стаціонарної допомоги в амбулаторну ланку, реструктуризації ліжкового фонду тощо)» [2]. Таким чином, найбільш важливою проблемою системи охорони здоров'я авторка вважає управління, а саме систему державного управління, від удосконалення якої залежить власне ефективність реалізації реформ, 3 одного боку, та результативність систем суспільного розвитку - $з$ іншого.

Багато вітчизняних учених, що працювали в таких галузях науки, як медицина, економіка, право, соціологія, державне управління, піднімали питання реформування системи охорони здоров'я та наслідків реформ, що були здійсненні в Україні. 3 метою іх оцінки розглянемо погляд учених та проаналізуємо найбільш важливі сучасні стратегії та програми реформування системи охорони здоров'я в Україні. 
Вітчизняні дослідники В.М. Лехан, Л.В. Крячкова, М.І. Заярський зазначають, що «в усіх пострадянських країнах, включаючи й Україну, в системах охорони здоров'я розпочалися перетворення, які стосувалися реорганізації організації, фінансування та надання медичних послуг. У дослідженні Європейського регіонального бюро ВООЗ та Європейської обсерваторії по системах і політиці охорони здоров’я було проаналізовано процеси перетворень, які відбувалися протягом двох десятиліть у системах охорони здоров'я 12-ти пострадянських країн (Вірменії, Азербайджану Білорусі, Грузії, Казахстану, Киргизстану, Республіки Молдова, Російської Федерації, Таджикистану, Туркменістану, України та Узбекистану), і встановлено, що трансформації відбувалися в усіх країнах, однак темпи, змістовне наповнення і результативність змін в охороні здоров'я різних країн істотно відрізнялися» [8, с. 5]. Загалом, погоджуючись із вченими, наведемо їхні підходи щодо реформування системи охорони здоров'я в Україні за певними етапами:

1) 1991-2000 pp.,

2) 2000-2010 pp.;

3) $2010-2013 \mathrm{pp}$.

4) 32014 р. і дотепер (табл. 1).

\section{Періодизація процесів реформування системи охорони здоров'я України}

Таблиця 1 за В.М. Лехан, Л.В. Крячковою, М.І. Заярським [8]

\begin{tabular}{|c|c|}
\hline Сутність & Характеристика \\
\hline 1 & 2 \\
\hline \multicolumn{2}{|r|}{$1991-2000 \mathrm{pp}$. } \\
\hline $\begin{array}{l}\text { у перше десятиріччя після } \\
\text { проголочення незалељності } \\
\text { реформи в системі охорони } \\
\text { здоров'я практично не про- } \\
\text { водилися }\end{array}$ & $\begin{array}{l}\text { зусилля уряду України і Міністерства охорони здоров’я (МОЗ) як центрального вико- } \\
\text { навчого органу влади у сфері охорони здоров’я були спрямовані на запобігання розвалу } \\
\text { сформованої системи охорони здоров’я і збереження мінімального рівня соціальних } \\
\text { гарантій забезпечення населення медичною допомогою }\end{array}$ \\
\hline \multicolumn{2}{|r|}{$2000-2010 \mathrm{pp}}$. \\
\hline $\begin{array}{l}\text { визначення основних напрямів } \\
\text { та механізмів реформування } \\
\text { СОЗ }\end{array}$ & $\begin{array}{l}\text { 1) пошук додаткових джерел фінансування охорони здоров’я (запровадження добро- } \\
\text { вільного медичного страхування, створення лікарняних кас - громадських неурядових } \\
\text { об’єднань громадян для добровільної солідарної участі населення в додатковому фінансу- } \\
\text { ванні охорони здоров’я); } \\
\text { 2) запровадження нових методів фінансування на рівні первинної ланки; } \\
\text { 3) автономізація постачальників медичних послуг; } \\
\text { 4) структурно-функціональні перетворення в системі медичної допомоги, в т.ч. реформу- } \\
\text { вання первинної медико-санітарної допомоги на засадах сімейної медицини; } \\
\text { 5) розвиток стаціонарозамінювальних форм надання медичної допомоги; } \\
\text { 6) регіоналізація родопомічної допомоги, а також комплекс підходів, спрямованих на } \\
\text { поліпшення якості медичного обслуговування }\end{array}$ \\
\hline \multicolumn{2}{|r|}{$2010-2013 \mathrm{pp}$} \\
\hline $\begin{array}{l}\text { проведення масштабної } \\
\text { реформи СОЗ у пілотних регі- } \\
\text { онах }\end{array}$ & $\begin{array}{l}\text { Реалізовані пілотні проекти щодо комплексного реформування системи охорони здоров’я, } \\
\text { найбільш ефективні з яких: } \\
\text { 1) розмежування первинної та вторинної медичної допомоги, пріоритетний розвиток } \\
\text { ПМД на засадах загальної практики - сімейної медицини, створення центрів ПМСд із } \\
\text { розвинутою мережею амбулаторій у містах і сільській місцевості; } \\
\text { 2) об’єднання (пулінг) фінансових ресурсів для надання вторинної та екстреної допомоги } \\
\text { на регіональному рівні; } \\
\text { 3) запровадження системи маршрутизації пацієнтів до закладів охорони здоров’я (3О3), } \\
\text { що відповідають важкості та складності захворювання, і створення лікарень інтенсивного } \\
\text { лікування як провідних закладів госпітальних округів; } \\
\text { 4) впровадження оплати праці за обсяги та якість роботи; } \\
\text { 5) запровадження державного регулювання цін на лікарські засоби для лікування осіб з } \\
\text { гіпертонічною хворобою з використанням порівняльних (референтних) цін і реімбурсації. }\end{array}$ \\
\hline \multicolumn{2}{|r|}{2014 p. idomenep } \\
\hline $\begin{array}{l}\text { комплексне реформування } \\
\text { системи охорони здоров'я роз- } \\
\text { почалося після певної паузи, яка } \\
\text { була зумовлена необхідністю } \\
\text { вироблення новим урядом під- } \\
\text { ходів до реформування галузі }\end{array}$ & $\begin{array}{l}\text { 1) систему державного регулювання цін на лікарські засоби та розширено спектр захво- } \\
\text { рювань із включенням серцево-судинних захворювань, бронхіальної астми та цукрового } \\
\text { діабету другого типу, на які поширюється механізм реімбурсації- повного або часткового } \\
\text { відшкодування вартості ліків; } \\
\text { 2) запроваджено цільове фінансування охорони здоров’я з державного бюджету у вигляді } \\
\text { медичної субвенції; }\end{array}$ \\
\hline
\end{tabular}


Закінчення таблиці 1

\begin{tabular}{|l|l|}
\hline 1 & \multicolumn{1}{|c|}{2} \\
\hline & 3) дозволено урядом фінансування 3ОЗ одночасно з державного та місцевого бюджетів \\
та/або одночасно з різних бюджетів; & 4) впровадження державного гарантованого пакета медичної допомоги; \\
5) пулінг бюджетних коштів для фінансування державних гарантій на національному \\
рівні зі створенням центрального органу виконавчої влади - Національної служби \\
здоров'я України (НСзУ) як єдиного закупівельника медичних послуг; \\
6) перехід від утримання мережі медичних закладів до стратегічної закупівлі медичних \\
послуг на договірних засадах; \\
7) автономізація постачальників медичної допомоги з набуттям більшістю з них статусу \\
некомерційних медичних підприємств та запровадження електронної системи охорони \\
здоров'я
\end{tabular}

Зазначений підхід до періодизації реформування системи охорони здоров'я країни показує, що реформи зачіпали такі складники даної сфери державного управління:

- організацію медичної допомоги через: розмежування первинної та вторинної медичної допомоги; маршрутизацію пацієнтів; розроблення гарантованого державою пакету медичної допомоги; впровадження системи забезпечення ліками; формування стаціонарозамінювальних форм надання медичної допомоги та інше;

- організацію управління закладами охорони здоров'я: автоматизацію постачальників медичної допомоги; впровадження оплати праці за обсяги та якість роботи; стратегічну закупівлю медичних послуг на договірних засадах;

- фінансування системи охорони здоров'я: запровадження нових методів фінансування; впровадження страхової медицини; цільове фінансування охорони здоров’я з державного бюджету у вигляді медичної субвенції;

- регулювання системи охорони здоров’я через систему державного регулювання цін на лікарські засоби.

А.Д. Барзилович [1] пропонує виділяти 4 етапи реформування системи охорони здоров'я в незалежній Україні, по кожному з яких виділяє сукупність нормативно-правових актів та дає характеристику. Варто зазначити, що періодизація реформ значно відрізняється від запропонованої авторами вище. Підхід А.Д. Барзиловича представлено в таблиці 2.

Таблиця 2

Основні етапи формування системи охорони здоров'я України

\begin{tabular}{|c|c|c|}
\hline Етапи & Нормативно-правові акти & Основні напрями реформування \\
\hline 1 & 2 & 3 \\
\hline 1991-1999 pp. & $\begin{array}{l}\text { Конституція України; Закон України «Основи зако- } \\
\text { нодавства України про охорону здоров’я» [12]; наказ } \\
\text { Міністерства охорони здоров’я України від } 27 \text { липня } \\
1998 \text { р. № } 226 \text { «Про затвердження Тимчасових галу- } \\
\text { зевих уніфікованих стандартів медичних технологій } \\
\text { діагностично-лікувального процесу стаціонарної } \\
\text { допомоги дорослому населенню в лікувально-про- } \\
\text { філактичних закладах України та Тимчасових стан- } \\
\text { дартів обсягів діагностичних досліджень, лікуваль- } \\
\text { них заходів та критеріїв якості лікування дітей» [16] }\end{array}$ & $\begin{array}{l}\text { Визначення правових, організаційних, } \\
\text { економічних та соціальних засад охорони } \\
\text { здоров’я в Україні }\end{array}$ \\
\hline 2000-2007 pp. & $\begin{array}{l}\text { Концепція розвитку охорони здоров’я населення } \\
\text { України [5]; Міжгалузева комплексна програма } \\
\text { «Здоров’я нації» [14]; Указ Президента України } \\
\text { «Про невідкладні заходи щодо реформування } \\
\text { системи охорони здоров’я населення» [16]; Націо- } \\
\text { нальний план дій («Дорожня карта реформування } \\
\text { системи охорони здоров’я») }\end{array}$ & $\begin{array}{l}\text { Початок упровадження інституту сімей- } \\
\text { ного лікаря, боротьба з найбільш поши- } \\
\text { реними та серйозними захворюваннями, } \\
\text { вдосконалення медичного обслугову- } \\
\text { вання, спроби запровадження страхової } \\
\text { медицини, впровадження стандартів } \\
\text { лікування на основі доказової медицини, } \\
\text { розвиток недержавного сектору медицини }\end{array}$ \\
\hline 2008-2014 pp. & $\begin{array}{l}\text { Національний план розвитку системи охорони } \\
\text { здоров’я на період до } 2010 \text { рр.; оновлений Закон } \\
\text { України «Основи законодавства України про охо- } \\
\text { рону здоров’я» [12] }\end{array}$ & $\begin{array}{l}\text { Розвиток первинної медико-санітарної } \\
\text { допомоги на засадах сімейної медицини. } \\
\text { Стандартизація, ліцензування та акреди- } \\
\text { тація медичних закладів }\end{array}$ \\
\hline
\end{tabular}


Закінчення таблиці 2

\begin{tabular}{|c|c|c|}
\hline 1 & 2 & 3 \\
\hline 2015-2020 pp. & $\begin{array}{l}\text { Національна стратегія реформування системи } \\
\text { охорони здоров’я в Україні на 2015-2020 роки } \\
\text { [11]; Закон України «Про внесення змін до деяких } \\
\text { законодавчих актів України щодо вдосконалення } \\
\text { законодавства з питань діяльності закладів охо- } \\
\text { рони здоров'я» [13] (автономізація постачальників } \\
\text { медичної допомоги) та інші }\end{array}$ & $\begin{array}{l}\text { Перехід до контрактної моделі закупівлі } \\
\text { медичних послуг. Запровадження нових } \\
\text { форм фінансування медичних закладів } \\
\text { та оплати праці медичних працівників. } \\
\text { Запровадження гарантованого державою } \\
\text { пакета медичних послуг. Створення єди- } \\
\text { ного замовника медичних послуг. Авто- } \\
\text { номізація постачальників медичної допо- } \\
\text { моги. Запровадження принципу «гроші } \\
\text { ходять за пацієнтом». Запровадження } \\
\text { соціального медичного страхування. } \\
\text { Розбудова сучасної системи управління } \\
\text { медичною інформацією }\end{array}$ \\
\hline
\end{tabular}

Зокрема, автор визначає такі напрями реформування, як: реформування первинної медико-санітарної допомоги; автоматизація постачальників медичної допомоги; запровадження соціального медичного страхування; стандартизація та акредитація медичних закладів.

Таким чином, кожен етап реформування системи охорони здоров'я характеризується змінами в таких складниках:

- економічний - визначаються напрями фінансування державної системи охорони здоров'я та формування системи оплати приватних медичних послуг, зокрема страхування;

- соціальний - визначаються напрями розвитку соціальної політики у сфері охорони здоров'я та формування напрямів надання медичної допомоги всім верствам населення, незалежно від соціального статусу, місця проживання й так далі;

- правовий - напрями правового регулювання функціонування державних закладів охорони здоров’я та ринку приватної медицини за всіма галузями медицини;

- організаційний - визначає порядок надання медичної допомоги на всіх рівнях (первинна, воринна, третинна) та напрями організації системи фінансування медицини.

І.П. Кринична, досліджуючи історичні аспекти реформування системи охорони здоров'я в Україні, виділяє такі етапи (табл. 3). Характеризуючи зазичений період, автор робить такі висновки: «За роки незалежності України значно скоротилося державне фінансування безоплатної для населення медичної допомоги. Розрахунок динаміки цін за різними видами витрат О3 свідчить, що обсяг державного фінансування з 1991 по 2001 р. зменшився на 2/3. Це дало підстави окремим авторам і політичним діячам для звинувачень уряду держави в неспроможності вирішувати соціальні питання. Однак справедливо зазначити, що безкоштовність медичної допомоги в СРСР мала обмежений характер, тому що багато провідних медичних технологій або не застосовувалися, або були доступні лише певній категорії населення» [7, с. 21].

У більші мірі автор визначав не особливості реформ, а їхні наслідки й, відповідно, стан системи охорони здоров'я в певному періоді.

Вітчизняні вчені В.М. Лехан, Г.О. Слабкий, М.В. Шевченко [8], досліджуючи питання стратегії розвитку охорони здоров'я в Україні, запропонували такі етапи реформування:

- I етаn - підготовчий - 2010-2012 pp.: 1) законодавче та нормативне забезпечення реформи; 2) розроблення органами місцевої влади всіх рівнів із залученням громадськості та за організаційнометодичної підтримки МО3 планів структурної реорганізації мережі закладів охорони здоров'я відповідно до потреб населення в медичній допомозі різних рівнів (первинній, вторинній, третинній); 3) створення за ініціативою МО3 незалежної структури для оцінки відповідності медичних закладів ліцензійним і акредитаційним вимогам (агенції з акредитації та ліцензування); 4) створення Всеукраїнського реєстру пацієнтів; 5) створення Фонду медичного страхування та його територіальні відділення, забезпечення їх устаткування та комплектування необхідними спеціалістами; 6) проведення апробації запропонованих змін на пілотних регіонах;

- II етап - 2013-2018 рр. - проведення реформування системи охорони здоров'я: 1) здійснення структурної реорганізації системи медичного обслуговування; 2) перехід до контрактної моделі закупівлі медичних послуг; 3) запровадження нових форм фінансування медичних закладів; 4) запровадження нових форм оплати праці медичного персоналу; 5) здійснення комплексу заходів щодо підвищення доступності ліків і забезпечення їхньої якості; 6) завершення проведення комплексу заходів, спрямованих на підвищення якості медичної допомоги; 7) запровадження соціального медичного страхування [8]. 
Таблиця 3

Характеристика етапів реформування системи охорони здоров'я в незалежній Україні

\begin{tabular}{|c|c|c|}
\hline Період & Eтап & Характеристика \\
\hline 1991-1994 pp. & Переоріснтація & $\begin{array}{l}\text { Помітно скоротилася управлінська вертикаль, управлінські } \\
\text { посади не завжди займали особи, досить компетентні з питань } \\
\text { управління, економіки, права і психології. Як результат - поси- } \\
\text { лення соціального напруження в галузі, відтік кадрів, погіршення } \\
\text { якості медичної допомоги, соціально-економічного та правового } \\
\text { захисту медичних працівників }\end{array}$ \\
\hline 1995-1998 pp. & Перехідний & $\begin{array}{l}\text { На фоні зниження основних демографічних показників, підви- } \\
\text { щення захворюваності на окремі соціально значущі хвороби } \\
\text { (туберкульоз, СНІД) і низьких загальних показників здоров’я } \\
\text { населення відзначалася деяка стабілізація політичної та соці- } \\
\text { ально-економічної ситуації в країні, в тому числі в галузі охорони } \\
\text { здоров’я. Так, формувалися перші ознаки ринкової економіки гос- } \\
\text { подарювання (виникло конкурентне середовище; зникав тоталь- } \\
\text { ний ринковий дефіцит медичних послуг, лікарських засобів, } \\
\text { медичної техніки, втрачало своє значення детальне централізо- } \\
\text { ване планування ОЗ), були прийняті основні закони в галузі ОЗ, } \\
\text { протокольно затверджена Кабінетом Міністрів України у 1997 } \\
\text { р. Концепція реформування галузі, яка визначала деякі напрями } \\
\text { загальної державної політики щодо ОЗ населення, а також фінан- } \\
\text { сувалися цільові науково-дослідні роботи, налагоджувалися між- } \\
\text { народні зв’язки з метою вирішення проблем ОЗ і надання медич- } \\
\text { ної допомоги в рамках програм «ТАСІЬ», «Здоров’я реформ», } \\
\text { «Трансформ» тощо. }\end{array}$ \\
\hline з 1999 p. & Умовно ринковий & $\begin{array}{l}\text { Період реформ в ОЗ можна оцінити як відносно ринковий, що } \\
\text { характеризується розробленням державної концепції реформу- } \\
\text { вання галузі та нової нормативно-правової бази, з’ясуванням } \\
\text { необхідності переходу на науково обгрунтовані моделі управ- } \\
\text { ління, визначенням загальної державної політики в галузі ОЗ } \\
\text { населення і перспективних напрямів щодо організації медич- } \\
\text { ної допомоги - впровадження сімейної медицини та медичного } \\
\text { страхування. }\end{array}$ \\
\hline
\end{tabular}

У контексті вказаних етапів розроблена авторами стратегія передбачала такі напрями вдосконалення системи охорони здоров'я: розмежування первинної та вторинної медичної допомоги; формування структури надання медичної допомоги в сільській місцевості; створення госпітальних округів; розроблення структури вторинної медичної допомоги; розвиток структури лікарень різних типів; розвиток відомчої та приватної медицини; запровадження договірних відносин у закупівлі медичних послуг; удосконалення системи управління закладами охорони здоров' я. Загалом запропоновані авторами пропозиції носять комплексний характер.

Ю.В. Вороненко та Н.Г. Гойда пропонують такі напрями реформування системи охорони здоров'я в Україні: «Щодо поліпшення надання медичних послуг реформою пропонується перш за все структурна перебудова, яка включає чітке розмежування первинного, вторинного і третинного рівня; забезпечення пріоритетного розвитку первинної медичної допомоги з акцентом на її профілактичний складник; запровадження сучасних механізмів організації медичної допомоги, як-то вільний вибір лікаря первинної ланки та систему направлень на вторинний і третинний рівень; запровадження дієвої системи управління якістю медичної допомоги із застосуванням медичних стандартів та клінічних протоколів, що базуються на надійних наукових даних» [3, с. 25]. Так, автор фактично погоджується з колегами щодо структурних перетворень, які полягають у визначенні чітких рис усіх трьох рівнів медичної допомоги, а також вагоме значення надає саме профілактичному складнику. Варто наголосити на позиції автора щодо якості медичних послуг та внесення змін в організацію процесів лікування.

У 2016 р. вітчизняний дослідник проблем охорони здоров’я I.С. Музика провів аналіз системи реформування досліджуваної галузі та виявив проблеми реалізації задекларованих реформ, на основі чого визначив такі проблеми:

- попри проголошення на державному рівні реформи фінансового забезпечення охорони здоров'я в Україні іiі реалізація в практичній площині залишається законодавчо не підтвердженою, що, відповідно, не дозволяє повною мірою змінити підходи до фінансування галузі; 
- удосконалення механізму фінансування (зокрема, введення медичної субвенції місцевим бюджетам), яке має місце нині, не враховує особливостей регіонів, а надалі відбувається за принципом «вирівнювання», що вимагає внесення уточнень і введення додаткових вагових коефіцієнтів у формульний підхід до розрахунку обсягів медичної субвенції за ії збереження далі;

- брак характерних особливостей у фінансуванні системи охорони здоров'я в областях Карпатського регіону. Тенденції щодо зростання обсягів видатків на галузь $є$ перманентними. Основні показники щодо фінансування видатків галузі як за економічною, так і за функціональною класифікаціями залишаються практично незмінними впродовж усього горизонту досліджень;

- оптимізація закладів охорони здоров'я, на жаль, на практиці відбувається за принципом «ліквідації касового розриву» між виділеними коштами і потребою в них, а не з метою поліпшення надання медичних послуг і приведення показників ефективності охорони здоров'я до світових стандартів;

- ухвалення рішень про оптимізацію мережі лікарських установ здебільшого не враховує потреб мешканців конкретних територій, розвиток транспортної інфраструктури, якості медичних послуг тощо, що є неприпустимим явищем, зважаючи на рівень надання медичних послуг, технічне оснащення установ, стан доріг, відстань між населеними пунктами, стан транспортного парку галузі на місцях тощо [9, с. 42].

Вітчизняний учений Я.А. Аркатов характеризує напрями реформування системи охорони здоров’я, що визначають позитивні зрушення:

«а) збільшення бюджетного фінансування медичної галузі;

б) забезпечення збалансованості обсягів державних гарантій надання населенню безоплатної медичної допомоги з фінансовими можливостями держави;

в) запровадження загальнообов'язкового державного медичного страхування;

г) координацію діяльності органів державної влади, місцевого самоврядування й суб'єктів медичного страхування;

д) підвищення ефективності використання всіх фінансових ресурсів;

е) забезпечення господарської самостійності медичних закладів і перехід до прогресивних форм їх господарювання;

є) підвищення рівня оплати праці та соціального захисту медичних працівників» [4, с. 54].

Визначені автором напрями $є$ загальними та не враховують у цілому галузеву специфіку та ті проблеми, з якими стикається система охорони здоров'я України. У більшій мірі зазначені напрями можна вважати завданнями, які стоять перед державним управлінням щодо реформування системи охорони здоров'я, у свою чергу зазначені завдання визначають зміст та форму реалізації тієї чи іншої реформи у сфері охорони здоров’я як ключової складової частини соціальної політики держави.

Висновки та перспективи подальших досліджень. За результатами проведеного дослідження нами визначені етапи реформування системи охорони здоров'я в Україні, які виділяються вітчизняними вченими, а також з'ясовано напрями, які ними пропонуються для вдосконалення. Загалом вважаємо, що для реалізації ефективних систем охорони здоров'я потрібно на державному рівні визначити стратегічні напрями розвитку досліджуваної галузі з обмеженням впливу політичних змін. Це дозволить забезпечити в повній мірі реалізацію стратегії та уникнути фрагментарних реформ.

\section{Література:}

1. Барзилович А.Д. Реформування системи охорони здоров’я в Україні: стратегічні аспекти. Інвестиції: практика та досвid. 2020. № 2. С. 134-140

2. Буранбаева Л.3. Реализация социально-ориентированной стратегии регионального развития на основе совершенствования инструментов управления системой здравоохранения. Казань, 2012. 20 с.

3. Вороненко Ю.В., Гойда Н.Г. Реформування охорони здоров я: успіхи та перешкоди. Сучасні медичні технологіï. 2013. № 2. C. 24-26.

4. Илюшкина О.В. Классификация факторов, влияющих на конкурентоустойчивость в системе оказания услуг в области здравоохранения. Экономический анализ: теория и практика. 2013. № 33 (336). URL: https://cyberleninka.ru/article/n/ klassifikatsiya-faktorov-vliyayuschih-na-konkurentoustoychivost-v-sisteme-okazaniya-uslug-v-oblasti-zdravoohraneniya (дата обращения: 15.12 .2020 ).

5. Концепція розвитку охорони здоров’я населення України : Указ Президента України від 07.12.2000 р. № 1313/2000. URL: https://zakon.rada.gov.ua/laws/show/1313/2000 (дата звернення: 15.12.2019).

6. Костюк В.C. Реформування охорони здоров'я в Україні в умовах європейської орієнтації. URL: http://www. vestnik-econom.mgu.od.ua/journal/2017/24-2-2017/11.pdf

7. Кринична І.П. Обгрунтування необхідності проведення реформування системи охорони здоров'я в Україні: історичний аспект. Аспекти публічного управління. 2015. № 3 (17). С. 19-26. 
8. Лехан В.М., Крячкова Л.В., Заярський М.І. Аналіз реформ охорони здоров’я в Україні: від здобуття незалежності до сучасності. Україна. Здоров'я наиії. 2018. № 4 (52). С. 5-11.

9. Музика I.C. Реформа охорони здоров'я: проблеми, аналіз, напрями реалізації (на прикладі Карпатського Регіону України). URL: http://ird.gov.ua/sep/sep20162(118)/sep20162(118)_038_MuzykaI.pdf

10. Національна стратегія реформування системи охорони здоров'я в Україні на період 2015-2020 pp. URL: https:// moz.gov.ua/strategija (дата звернення: 22.12.2019).

11. Основи законодавства України про охорону здоров’я : Закон України від 19.11.1992 p. № 2801XII. URL: https:// zakon.rada.gov.ua/laws/show/280112 (дата звернення: 22.12.2019).

12. Про внесення змін до деяких законодавчих актів України щодо удосконалення законодавства 3 питань діяльності закладів охорони здоров’я : Закон України від 06.04.2017 р. № 2002VIII. URL: https://zakon.rada.gov.ua/laws/ show/200219 (дата звернення: 22.12.2019).

13. Про затвердження Міжгалузевої комплексної програми «Здоров’я нації» на 2002-2011 роки : Постанова Кабінету Міністрів України від 10.01.2002 p. № 14. URL: https://zakon.rada.gov.ua/laws/show/142002\%D0\%BF (дата звернення: 15.12.2019).

14. Про затвердження Національного плану розвитку системи охорони здоров'я на період до 2010 року : Постанова Кабінету Міністрів України від 13.06.2007 р. № 815. URL: https://zakon.rada.gov.ua/laws/show/8152007\%D0\%BF (дата звернення: 22.12.2019).

15. Про невідкладні заходи щодо реформування системи охорони здоров'я населення : Указ Президента України від 06.12.2005 p. № 1694/2005. URL: https://zakon.rada.gov.ua/laws/show/1694/2005 (дата звернення: 15.12.2019). 